\title{
Metaplastic carcinoma of the breast: a clinical and pathological study of 40 cases \\ Verónica Arce-Grijalva ${ }^{1}$, Teresa Vela-Chávez ${ }^{1}$, Víctor M Pérez-Sánchez ${ }^{1}$ and Eva Ruvalcaba-Limón*2
}

\author{
Address: ${ }^{1}$ Departamento de Patología - Tumores mamarios, Instituto Nacional de Cancerología and ${ }^{2}$ Departamento de Oncología Mamaria, \\ Instituto de Enfermedades de la Mama - FUCAM.México City, Mexico \\ Email: Eva Ruvalcaba-Limón* - evaruvalcaba@yahoo.com.mx \\ * Corresponding author
}

from 24th Annual Meeting of the National Cancer Institute of Mexico

Mexico City, Mexico. 14-17 February 2007

Published: 5 February 2007

BMC Cancer 2007, 7(SuppI I):A6 doi:10.1186/1471-2407-7-SI-A6

This article is available from: http://www.biomedcentral.com//47I-2407/7/SI/A6

(C) 2007 Arce-Grijalva et al; licensee BioMed Central Ltd.

\section{Background}

Metaplastic carcinoma of the breast $(\mathrm{MCB})$ is a rare neoplasm, described in approximately $1 \%$ of all breast carcinomas. $\mathrm{MCB}$ is associated with poor prognosis and correlated with a high recurrence rate and visceral metastases. MCB is generally hormonal receptor-negative; specific treatments are not well defined. The objective of this study was to describe the clinical and pathological features of $\mathrm{MCB}$.

\section{Materials and methods}

We included all the patients with diagnosis of MCB, treated in Instituto Nacional de Cancerología (INCan) of México City during the period from 1995 to 2005; all cases had histopathological confirmation by two pathologist. Clinical information, pathological features of the tumor and survival information were collected; descriptive analysis was done.

\section{Results}

From 1995 to 2005 the Instituto Nacional de Cancerologia attended 6,610 breast cancer cases; during this period we found $40(0.6 \%)$ cases of MCB, all of them were female with a mean age of 47.9 years old (24-74). Based on the WHO classification, 20 cases were purely epithelial and 20 were mixed. Of purely epithelial cases, 8 (20\%) were squamous, 9 (22.5\%) spindle cell and $3(7.5 \%)$ adenosquamous. Mixed cases with chondroid metaplasia, osseous metaplasia and carcinosarcoma, were 15 $(37.5 \%), 3(7.5 \%)$ and $2(5 \%)$ patients, respectively. The right breast were more affected than left (58\% vs. $42 \%$ ). Clinical stages I, II and III were 5\%, 35\% and 52.5\%, respectively; no stage IV were documented. All patients but 2 underwent surgery treatment. Relapse occurred in 10 cases $(30.3 \%)$; recurrence sites were $2(20 \%)$ local and $8(80 \%)$ distant, frequently the bone. Overall survival was 45.2 months. Table 1 shows clinical and pathological features between purely epithelial and mixed types of MCB.

\section{Conclusion}

The prevalence of MCB in INCan from 1995 to 2005 is $<1 \%(0.6 \%)$, with the same distribution between purely epithelial and mixed types. Patients with mixed MCB tended to be younger, with larger tumors, and less survival than the purely epithelial group. Clinical stage, type of surgery, systemic treatment, adjuvant treatment and recurrence where similar between both different histological types. 
Table I: Clinical and pathological features between purely epithelial and mixed epithelial MCB.

\begin{tabular}{|c|c|c|c|}
\hline & All cases & Purely epithelial & Mixed epithelial and mesenchymal \\
\hline Mean age (years) $(n=40)$ & 47.9 & 49.4 & 46.4 \\
\hline \multicolumn{4}{|l|}{ Breast side $(n=38)$} \\
\hline Right & $22(58 \%)$ & $10(52.6 \%)$ & $12(63.1 \%)$ \\
\hline Left & $16(42 \%)$ & 9 (47.3\%) & $7(36.8 \%)$ \\
\hline Mean tumor size $(\mathrm{cm})$ & $7.16(1.8-40)$ & $5.79(2-11)$ & $8.31(1.8-40)$ \\
\hline \multicolumn{4}{|l|}{ Clinical stage } \\
\hline I & $2(5 \%)$ & 0 & $2(10.5 \%)$ \\
\hline II & $14(35 \%)$ & $8(42.1 \%)$ & $6(31.5 \%)$ \\
\hline III & $21(52.5 \%)$ & $10(52.6 \%)$ & II (57.9\%) \\
\hline Non-classifiable & $3(7.5 \%)$ & & \\
\hline \multicolumn{4}{|l|}{ Outcome $(n=33)$} \\
\hline No relapse & $20(60.6 \%)$ & & \\
\hline Relapse & $10(30.3 \%)$ & & \\
\hline Progression of disease & $3(9.1 \%)$ & & \\
\hline \multicolumn{4}{|l|}{ Recurrence site } \\
\hline Local & $2(20 \%)$ & I (20\%) & I (20\%) \\
\hline Distant & $8(80 \%)$ & $4(80 \%)$ & $4(80 \%)$ \\
\hline Overall survival (months) & 45.2 & 49.9 & 40.5 \\
\hline
\end{tabular}

Publish with Biomed Central and every scientist can read your work free of charge

"BioMed Central will be the most significant development for disseminating the results of biomedical research in our lifetime. " Sir Paul Nurse, Cancer Research UK Your research papers will be:

- available free of charge to the entire biomedical community

- peer reviewed and published immediately upon acceptance

- cited in PubMed and archived on PubMed Central

- yours - you keep the copyright 